\title{
Overview of Pathology and Laboratory Features of COVID-19
}

\author{
Oluwaseyi Eunice Bamisaye*, Funmilayo Ajoke Adewumi, Ayodeji Blessing Ajileye \\ Department of Biomedical Laboratory Science, Faculty of Basic Medical Science, College of Medicine, University of Ibadan, Nigeria
}

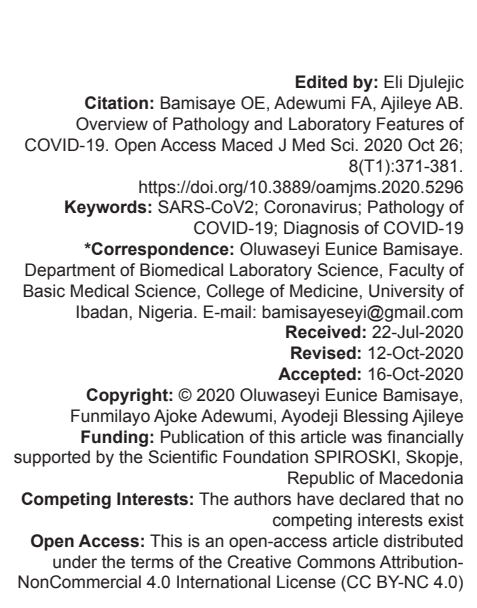

Abstract

BACKGROUND: The third identified severe respiratory disease in the past two decades and the first to result in a pandemic is the coronavirus disease 2019 (COVID-19) specifically caused by the severe acute respiratory syndrome coronavirus-2 (SARS-CoV-2).

AIM: The aim of this study was to provide an overview of the basic pathology and diagnostic laboratory features of COVID-19.

METHODS: This review involved search of literatures on PubMed, Science alert, Medline, and Advanced Google search using the keywords "SARS-CoV2," "Coronavirus" along with "pathology of COVID-19" and "diagnosis of COVID-19" with related articles pooled, relevant information extracted, and properly referenced

RESULTS: The recommended method of diagnosis is by nucleic acid testing of the viral ribonucleic acid in which realtime reverse-transcription polymerase chain reaction followed by nucleic acid sequencing when required is performed while some serologic techniques developed include enzyme-linked immunosorbent assay, immunochromatographic lateral flow assay, neutralization bioassay, and specific chemosensors to detect the immunoglobulin $M$ and immunoglobulin $\mathrm{G}$ antibodies produced, although sole use of serologic tests is highly discouraged by monitoring agencies. The hematological features display leukocytosis with lymphocytopenia, eosinopenia, reduced procalcitonin along with increased D-dimer, C-reactive protein, serum amyloid A, fibrin, fibrin degradation products, and some inflammatory markers such as interleukin (IL)-2, IL-6, IL-7, IL-10, granulocyte colony-stimulating factor, MCP10, interferon gamma-induced protein 10, and tumor necrosis factor- $\alpha$. The pathologic presentations include pleurisy, lung consolidation, pulmonary edema and pericarditis along with other features of acute respiratory syndrome, myocardial injury, and acute kidney injury.

CONCLUSION: There are highly efficacious and reliable methods of diagnosis of COVID-19 which also determine the stage and severity of the condition, and these methods are performed in line with specific clinical presentations. However, more studies are required to identify the capabilities, characteristics, and tendencies of this novel virus.

\section{Introduction}

Coronavirus disease 2019 (COVID-19), a latest outbreak proclaimed as a pandemic by the World Health Organization (WHO), is a diseased condition resulting from infection of the severe acute respiratory syndrome corona virus-2 (SARS-CoV-2) [1]. The disease was named on February 11, 2020, by the WHO and subsequently declared a pandemic, on March 11, 2020 [2], [3], when it was recorded that there were more than 118,000 cases in 114 countries and 4291 deaths as a result of its rapid spread through human to human transmission by aerosol droplets to all continents of human existence with 13-fold increase [4]. COVID-19 is the third identified severe respiratory illness caused by the coronavirus in the past two decades and the first to cause a pandemic [4]. Others such as SARS and Middle East respiratory syndrome (MERS) have been earlier identified possessing similar susceptibility [5].

SARS-CoV-2 was classified by the International Committee on Taxonomy of Viruses (ICTV) as a newly identified strain of ribonucleic acid (RNA) viruses which had not been previously isolated in humans until recently when it was discovered to be transmitted from human to human resulting in series of respiratory tract disorders, ranging from various levels of severity which commenced in Wuhan, China [6], [7], [8], [9]. The complete genome sequencing information from two assemblage revealed that the SARS-CoV-2 comprises six major open reading frames and shares approximately $80 \%$ of similarity with SARS-CoV, but $98.65 \%$ nucleotide identity to partial RNA-dependent RNA polymerase (RdRp) gene and $96.2 \%$ identity to RaTG13 of SARS-related CoronaVirus family found in bats, respectively [6], [10], [11], [12].

Globally, as at July 17, 2020, there have been 13,616,593 confirmed cases of COVID-19, including 585,727 deaths with $7,154,840 ; 3,008,972$; $1,346,792 ; \quad 1, \quad 308,441 ; \quad 543,122 ;$ and 253,495 confirmed cases in America, Europe, Eastern Mediterranean, South-East Asia, Africa, and Western pacific continents, respectively [13], [14]. Despite the documentedcomparativelylowmortality, thetransmissibility of COVID-19 is observably elevated [15], [16]. This transmissibility potential is the $R_{0}$ value which 
is a pointer of the viral ability to transmit, thereby representing the average figure of new infections produced by an infectious person in a an uninfected populace. When $R_{0}>1$, this indicates that there is the possibility of increased infection while $R_{0}<1$ indicates the fading off of transmission. An essential concept of infectious disease epidemiology is the reproduction number which indicates the menace associated with the endemic spread of an infectious agent [17]. The basic reproduction number $\left(R_{0}\right)$ of COVID-19 has been estimated to range from 1.4 to 6.47 , while some studies have shown the $R_{0}$ value to be $>3$ [16], [17], [18].

The COVID-19 is characterized by various degenerative symptoms such as pyrexia, dry or hoarse cough, sputum, gasping or cessation of breath, loss of taste sensation and/or smell, exhaustion, and lymphopenia in infected persons with the infections causing viral pneumonia which may lead to SARS and mortality in more severe cases or persons with underlining conditions such as diabetes and hypertension [6], [7], [8], [9], [19].

With the current trend in the management, epidemiology and occurrences in this pandemic, this review attempts to appraise the pathology, diagnosis, and laboratory features of COVID-19.

\section{Methodology}

This review involved search of the literatures on PubMed, Medline, Science alert, and Advanced Google search using the keywords "SARS-CoV2," "Coronavirus" along with "pathology of COVID-19" and "diagnosis of COVID-19"in this text with related articles pooled and relevant information extracted, and properly referenced. From the search, we obtained 205 (220) articles out of which relevant information for this study were specifically extracted from 96 of the publications for this article.

\section{Pathogenesis of COVID-19 infection}

Coronaviruses are a family of enveloped singlestranded RNA viruses with zoonotic features, and clinical signs analogous to the regular flu, neurological, severe respiratory, hepatic, and gastrointestinal symptoms [4], [20]. The six other identified coronaviruses which can infect humans aside the SARS-CoV-2 [21], are HCoV-229E, HCoV-OC43, SARS-CoV, HCoV-NL63, HCoV-HKU1, and MERS-CoV [6], [21], [22], [23]. They have created two major pandemics in the past 20 years which are the SARS [24] and MERS [11], [21], [25]. In detection of the major source of COVID19, China Centre for Disease Control (CDC) analysts pointed that it originated from wild animals that are sold in the Wuhan local market (Chinese CDC, 2020). The researchers obtained and analyzed throat swab, lung fluid, and blood samples of 15 patients infected with the virus. The analyses discovered that the virus-specific nucleic acid sequences in the sample differ from those of previously known human coronavirus (hCoV) species displaying that SARS-CoV-2 has similar properties to some of the beta $(\beta)$ coronaviruses genera identified in bats [8], [11], [26], [27], among the SARS/SARS-like CoV group [11], [21].

The outcome of the next-generation sequencing performed by these researchers indicated that the features of SARS-CoV-2 differ from SARS-CoV (with about $79 \%$ sequence identity) and MERS-CoV (with about $50 \%$ sequence identity) than from the group of two bat-derived SARS-such as coronaviruses - bat-SLCoVZC45 (with $87.9 \%$ sequence identity) and bat-SLCoVZXC21 (with $87.2 \%$ sequence identity) [28]. Studies also reported that COVID-19S-protein supported strong relationship with human angiotensin converting enzyme 2 (ACE2) molecules in spite of the variation in its sequence with that of SARS-CoV [11], [21], [29]. Although detailed pathogenesis of this novel infection is emerging day by day, the mechanism of infection has been described to entail the adhesion of the viral spike protein to the ACE2 molecule of the type II pneumocyte receptor (a precursor of type I pneumocyte) and the virion is endocytosed by the help of a serine protease TMPRSS2. On entering the cell, the virion RNA is released and translated by the cells machinery into non-structural polyproteins that are cleaved into proteases, which are RNA-dependent, RNA polymerases, and structural proteins. Then replication complex forms to produce more RNA with viral proteins and RNA assembling into a newly manufactured virion in the Golgi consequently releasing the virion to infect new Type II pneumocytes [30]. This, in turn, result in aggressive inflammatory response leading to vascular endothelial dysfunction and subsequently endotheliopathy, with sepsis-induced coagulopathy (SIC) as described by the international society for thrombosis (ISTH) [31], [32]. The SIC in COVID-19 could occur by activation of coagulation through several procoagulant pathways such as viral adhesion on an ACE2 receptor present on endothelial cells, inflammatory cell infiltration coupled with apoptosis of endothelial cells, and microvascular prothrombotic effects [33] which explains the myocardial ischemia and increasing reports of macro- and micro-thromboembolic complication in some patients [33], [34], [35].

Furthermore, the pathobiology of this process has been further classified into three stages [36] which are: The asymptomatic state occurring within 1-2 days of infection whereby the inhaled virus will bind the epithelial cells of the nasal cavity through the assistance of the ACE2 receptors with the consequent initiation of a limited innate immune response [37], [38]; the next stage is symptomatic phase characterized by the upper and conducting airway response occurring within few days of infection triggering a more robust innate immune response evidenced with the presence 
of beta and lambda interferons, especially C-X-C motif chemokine ligand 10, an excellent interferon responsive gene to the alveolar type 2 cell in SARS and influenza infection. Finally, the third stage is associated with hypoxia, ground-glass infiltrate with progression to acute respiratory distress syndrome (ARDS) which occurs as the virus reaches the gas exchange units of the lung infecting the peripheral and subpleural alveolar type II cells leading to apoptosis and cell death. This, in turn, will trigger a secondary pulmonary epithelial regeneration as was seen in influenza pneumonia [36], [39], [40]. The recovery will, however, require an energetic innate and acquired immune response coupled with aggressive pulmonary epithelia regeneration which is quite slow in the elderly due to their diminished immune response and reduce ability to regenerate or repair damaged epithelial cells [36].

\section{Laboratory diagnosis of COVID-19}

The diagnosis of the infection is majorly by molecular methods whereby reverse-transcriptase polymerase chain reaction (RT-PCR) is the choice technique [41], [42], [43], [44], [45]; serological tests have been developed by CDC (2020) for optimization and validation of other serologic reagents manufactured for diagnostic purposes. The severity of the condition can also be evaluated by the various laboratory analyses, across the hematology, chemical pathology, histopathology, microbiology and immunology field, so as to correlate their results with the clinical manifestation in the management of the patients.

\section{Specimens for diagnosis}

To ensure accurate diagnosis of the viral pneumonia infection (COVID 19), collecting good quality and the correct specimen from the patient promptly are important. According to the CDC guidelines, upper and lower respiratory specimens such as throat swab, nasal nasopharyngeal (NP) swab, sputum, and bronchial fluid are recommended [46]. In patients with more severe respiratory disease, upper respiratory specimens such as NP and oropharyngeal (OP) swab including lower respiratory specimens such as sputum (SP) and endotracheal aspirate or Bronchoalveolar lavage can be used. Previously, Wang et al. reported that OP swabs were used more often than NP specimen in China during the COVID-19 outbreak and that SARS-CoV-2 RNA was significantly detected in NP swabs [47]. The CDC also recommended the collection of the upper respiratory swab. Collection of an OP specimen was considered of a lower priority and when collected may be combined in a single tube as the NP swab [46]. Swab specimens are recommended to be placed and transported in a universal or viral transport medium or stored $2-8^{\circ} \mathrm{C}$ for up to $72 \mathrm{~h}$ after collection. Specimens can be stored at $-70^{\circ} \mathrm{C}$ or below when a delay in testing or shipping is anticipated [46]. In addition, Cheng et al. have recommended the collection of both upper and lower respiratory samples such as Sputum and Broncho alveolar lavage fluid [48]. SARS-CoV-2 has also been detected from urine, stool, and blood specimens, although less frequently than from respiratory specimens. Cheng et al. publish that $70 \%(n=38)$ of the fecal specimen at the peak of viral (9-11 days) shedding was positive following testing. Furthermore, a case report by Tang et al. have recorded a positive test in an asymptomatic child who was positive for the 2019 novel coronavirus by rRTPCR from stool specimen even 9 days after respiratory tract specimens were negative [49]. The use of nucleic acid detection of COVID-19 in fecal specimens has been appraised to be equally accurate in diagnosis [7]. Likewise, the use of serum for the detection of SARSCoV-2 has been previously reported. Zhang et al. showed that serological tests can improve detection rate and recommended its usage in future epidemiological studies [50]. Rectal sourced specimens have likewise been reported positive in patients infected with SARSCoV-2 [51].

\section{Molecular diagnosis}

SARS-CoV-2 is a single-stranded positivesense RNA virus and its entire genetic sequence was uploaded to the Global Initiative on Sharing All Influenza Data platform on January 10, 2020. The sequence data have since been helpful in designing primers and probes useful for the molecular diagnosis of SARS-CoV-2 [49], [52]. According to the WHO's guidelines, nucleic acid amplification tests (NAAT) for COVID-19 SARS-CoV-2 have been recommended. Routinely, confirmation of COVID-19 casesis based on detection and analysis of the sequences of virus RNA by NAAT such as real-time rRT-PCR, followed up by nucleic acid sequencing when required. The viral genes usually targeted include the N, E, S, and RdRP genes [53]. It is recommended that RNA extraction is done avoiding contamination in a biosafety cabinet in a BioSafetyLevel-2. Heat treatment of samples before RNA extraction is not recommended [54], [55]. A major advantage in the use of molecular diagnostic strategy is its ability to detect a positive case in an asymptomatic population thus preventing the spread of the virus to close contact. A study by Mizumoto et al., on the passengers ( $n=3,711$ ) on a diamond princess cruise ship tested for SARS-CoV-2 revealed an estimated asymptomatic proportion (among all infected cases) at 17.9\% (95\% Crl: 15.5-20.2\%) [56].

\section{$R T-P C R$}

$\mathrm{RT}-\mathrm{PCR}$ is recommended as the gold standard detection method for the identification of SARS-CoV-2 virus and relies on the principle of amplifying a small 
amount of viral genetic components in a sample. At present, RT-PCR test for SARS-CoV-2 has been used to test samples collected from the upper respiratory system using swabs. There are studies which have employed the use of this method in identification of SARS-CoV-2 in serum, stool, and other specimens [57], [58]. Although RT-PCR is the most widely used method for detecting SARS-CoV-2 infections, its major limitation is that it requires expensive laboratory instrumentation and reagents as well as highly skilled laboratory personnel to man such laboratories. Thus, a number of companies and laboratories around the globe are working on means of improving the efficiency and timeliness of the RT-PCR technologies and developing various other diagnostic methods [52].

Other molecular techniques in use include: Isothermal nucleic acid amplification which allows gene amplification at a constant temperature and eliminates the need for a thermal cycler [59]. This principle is used in reverse-transcription loop-mediated isothermal amplification (RT-LAMP). RT-LAMP provides an alternative and a more rapid and cost-effective testing method for SARS-CoV-2 but requires a set of four primers to target the genes and enhances the sensitivity of the test with a reverse-transcription step to allow for the detection of RNA. The amplified product can be detected using a photometric apparatus to measure the turbidity caused by magnesium pyrophosphate precipitated in the solution as a byproduct of amplification [52]. The reaction can be monitored in real time by measuring the turbidity or fluorescence using intercalating dyes since RT-LAMP diagnostic testing requires heating and visual inspection. The simplicity and sensitivity of this technique make it a promising candidate for virus detection [52], [60].

Microarrays have equally provided a rapid and high-throughput detection for SARS-CoV-2 nucleic acids. This technology relies on the use of reverse transcription to generate complementary DNA (cDNA) from viral RNA and subsequently labeling the cDNA with specific probes. In principle, the arrays are prepared either by an in situ synthesis of biomacromolecules on solid substrates or by spotting ex situ synthesized biomacromolecules on a substrate surface [61]. This is followed by loading the labeled cDNAs into the wells of microarray trays containing solid-phase oligonucleotides attached onto their surfaces. If hybridized and after washing away the unbound DNA, they remain bound, signifies the presence of virus-specific nucleic acid [41]. The use of microarray assay has been previously reported and identified as a useful tool in detecting mutations associated with SARS-CoV-2 [53], [54]. Guo et al. detected and characterized viral strains with $100 \%$ accuracy and thus recommended this method for the detection and epidemiological surveillance for SARSCoV-2 [62], [63]. At present, more studies are needed to further substantiate and to evaluate the sensitivity of this method in SARS-CoV-2 diagnosis especially in Africa.

\section{Serological and Immunological assays}

Serologic assays have important public health applications in the current COVID-19 response. RT-PCR-based viral RNA identification has been used globally and appraised as the gold standard in diagnosis of COVID-19 but has inability to monitor the progress of the disease stages and cannot be applied to the identification of past infection and immunity [52]. It is believed that serologic testing can aid the understanding of disease patterns and transmission as well as improve data collection from serologic surveys among different ethnic groups and populations [64].

Serologic testing involves analysis of blood serum or plasma and other biological fluids. In principle, it involves recognition of antibodies, which are specific proteins produced in response to infections. This screening method plays an important role in epidemiology and vaccine development. It also provides an assessment of both short-term (days to weeks) and long-term (years) trails of antibody response in the tested population. Immunoglobulin M (IgM) first becomes detectable in serum after few days and lasts for some weeks on infection. This is usually followed by a switch to immunoglobulin $\mathrm{G}$ ( $\mathrm{lg} G)$. Thus, IgM may be used as an indicator for early stage of infection and $\lg G$ is indicating a current or prior infection. IgG may also be used to suggest the presence of post-infection immunity. In the recent COVID-19 pandemic, serologic tests have been identified to have huge potential for the epidemiology of COVID-19 [64].

However, the United States' CDC has cautioned on the direct adoption of serologic testing for SARSCoV-2 as more studies are needed to comprehend if the antibodies produced from SARS-CoV-2 infection will confer immunity from a future infection. CDC scientists are conducting studies to better understand the level of antibodies needed for protection, the duration of such protection, and the factors associated with whether a person develops a protective antibody response [64]. The U.S. Food and Drug Administration (FDA) recommended (revised policy) that the use of serologic tests and reagents intended for antibody detection to SARS-CoV-2 to identify people who may have been exposed to the SARS-CoV-2 virus or who have recovered from the COVID-19 infection be subjected to validation and approval, it was also emphasized that serological (antibody) tests should not be used as the sole basis to diagnose COVID-19 [65].

The serologic techniques in use include the enzyme-linked immunosorbent assay (ELISA), immunochromatographic (ICG) lateral flow assay, neutralization bioassay, and specific chemosensors. They vary in speed, multiplexing, automation, as well as limitations such as requirements for trained personnel and availability of dedicated laboratories. The FDA had earlier granted emergency use authorization status to the first serology test, qSARS-CoV-2 IgG/lgM Rapid Test, manufactured by Cellex Inc., on April 1, 2020 [65]. 
A study by Pan et al. demonstrated the serologic ability of ICG strips in identifying SARS-CoV-2 infection to be sensitive and consistent and thus considered it as an excellent complementary approach in clinical application [66]. In another study, Haveri et al. assessed the presence of neutralizing antibody response along with specific $\lg M$ and $\lg G$ targeting nucleocapsid and spike proteins and recommended this technique has a candidate test which can enhance better understanding of SARS-CoV-2 infection. However, monitoring of the binding antibodies is suggested to be a more sensitive method than measuring functional neutralizing antibodies for serological detection of hCoV infections [67].

\section{Hematological features and other laboratory findings}

The hematological analysis reported by various researchers include the total leukocyte count, lymphocyte, eosinophils, monocyte, platelet counts, D-dimer, procalcitonin (PCT), serum amyloid A (SAA), erythrocyte sedimentation rate (ESR) and they are categorized based on the concentration of parameters, severity of disease (severe and non-severe conditions), 5 and 4-days post-hospital presentation, and complication conditions as represented in Table 1 obtained from the studies by Zhang et al. and Bingwen et al. [1], [68]. Zhang et al. reported that the total leukocyte count, D-dimer, C-reactive protein (CRP) $(p<0.001)$, and SAA were increased in patients with severe condition than those whose conditions were not severe while decreased value was observed in lymphocyte, eosinophils, and PCT in severe conditions with observable lymphopenia and eosinopenia at 5 days post-clinical presentation. The population distribution demonstrated $12.3 \%$, $43.2 \%, 34.7 \%$, and $90.2 \%$ of the COVID-19 positive population had increased leukocyte, D-dimer, PCT, and SAA, respectively, while $19.6 \%, 75.4 \%$, and $52.96 \%$ had decreased leukocyte, lymphocyte, and eosinophil counts, respectively [1]. In addition, corroborating work by Bingwey et al. reported similar white cell results along with moderate platelet count and hemoglobin concentration [68]. Some other studies that relate COVID19 infection with thrombosis also observed increased level of $\mathrm{D}$-dimer along with increase in some other coagulation markers such as fibrin, fibrin degradation products (FDP) with minimal change in prothrombin time, activated partial thromboplastin time, and platelet count which are pointers of thrombosis as reviewed by Connors et al. and Robbin et al. [32], [69]. In addition, the assessment of 11 patients in the intensive care unit in Italy display reduced mean antithrombin concentrations with slightly low protein $S$ free antigen along with an increased mean VWF and vWF-ristocetin cofactor activity [70]. These observations coupled with other severe thrombotic developments led the ISTH developing an interim guidance on recognition and management of coagulopathy in COVID-19 whereby D-dimer, prothrombin time, platelet count, and fibrinogen (if fibrinogen measurement is feasible) are to be measured

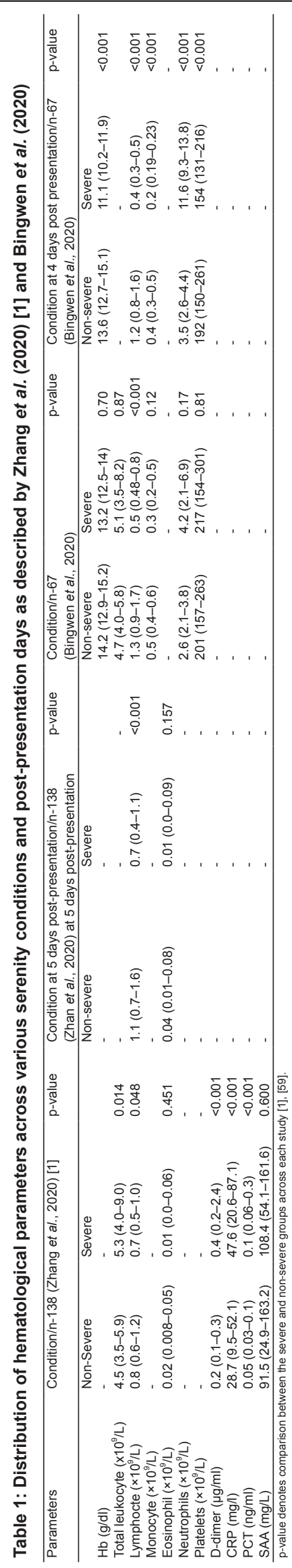


in patients presenting with COVID-19. The patients with abnormal results are to be admitted and subsequent treatment (heparin or blood product transfusion) based on the severity of results obtained [71].

Furthermore, another study by Shuchang et al. on the CT features of COVID-19 infected persons with pneumoniain some62 patients in Wuhan, China, observed that the routine blood analyses conducted on 30 of the patients displayed $6(20.0 \%), 24(80.0 \%)$, and $15(50.0 \%)$ with leucopenia, lymphocytopenia, and decreased percentage of lymphocytes, respectively [72]. The ESR and high-sensitivity CRP level assessed yielded $66.7 \%$ and $100 \%$ elevated values for both parameters, respectively, thus are corroborating the report of the study by Zhang et al. [1]. A usual or diminished total white blood cell count along with reduced lymphocyte count can be demonstrated in the early phase of the infection as researched by Cascella et al. [73]. Furthermore, their article reported that lymphopenia is visibly negative prognostic factor for COVID-19 infection with amplified values of CRP and standard procalcitonin value. In severe condition, it was reported that D-dimer value is augmented, blood lymphocytes declined persistently, and analytical variations of multiple organ imbalance evident by high amylase as well as disordered coagulation activities [73].

In addition, leukopenia, lymphocytopenia, and eosinophil cytopenia were observed to be recurrent in COVID-19 induced pneumonia more than those in non-COVID-19 induced pneumonia [74]. Furthermore, a marked reduction in CD4 and CD8 lymphocytes series was noted at the onset phase of the disease by Wang et al. [8] with patients in the critical care facility displaying higher levels of interleukin (IL) 2, IL-10, IL-7, monocyte chemotactic protein 1 (MCP1), granulocyte colony-stimulating factor (GCSF), interferon gammainduced protein 10 (IP10), tumor necrosis factor- $\alpha$ (TNF- $\alpha$ ) and macrophage inflammatory protein alpha along with other abnormal coagulation, and cell count parameters described by some other researchers [7], [75]. The lung injury presentation in this infection has been strongly analyzed by emerging evidences to result from the excessive release of pro-inflammatory markers such as IL-1, IL-6, and TNF- $\alpha$ and interferon, a situation called cytokine storm [76]. This is because their secretion results in influx of immune cells into the site of infection producing destructive effects on tissues damaging cell interaction, multi-organ failure, and eventual death [77]. This is ascertained by the further analysis of cytokines in infected patients with the observation that they are increased in patients and even more elevated in severe cases [7], [78], [79], [80], [81], [82] as well as in children from ages 2 months to 15 years [83].

In addition, infected individuals with blood Group A were studied to be significantly most-at-risk for contracting COVID-19 compared with non-A blood groups while blood Group $\mathrm{O}$ has a appreciably lower risk for the infection compared with non-O blood groups as reported by some researchers in Wuhan, China [19]. Although, there are still some categorical questions concerning the study with regard to the distribution of blood groups in China populace, ethnicity, and statistical inferences.

\section{Histopathological features of COVID-19}

The macroscopic view of COVID-19 is observed more to be in the chest and can also include pleurisy, lung consolidation, pulmonary edema, and pericarditis. The weight of the lung may increase above normal. It can also be noted that a secondary infection can be super imposed on the viral infection which can lead to purulent inflammation that is more of a typical bacterial infection [84]. A recent article explained the early pathological features in COVID-19 in two patients who had gone through surgical resections for lung adenocarcinoma, but it was later discovered during the procedure of the operation that the two patients had COVID-19 [11]. The findings obtained were not specific and these include edema, pneumocyte hyperplasia, focal inflammation, and multinucleated giant cell formation, while hyaline membranes were not observed. These patients did not show any symptoms of COVID-19 as at the time of the operation; these are likely to reflect only in the early changes of acute lung injury in the infection [11].

Furthermore, a reported case of biopsy samples from 50 years deceased of COVID-19 in Wuhan city, China, was harvested from the liver, lungs, and heart organs of the patient. Histomorphological examination revealed bilateral diffuse alveolar damage with cellular fibromyxoid exudates [85]. The right lung revealed evident of desquamation of pneumocytes and hyaline membrane formation, which indicates an ARDS. The left lung showed pulmonary edema with hyaline membrane formation, which suggests of early-phase ARDS [85]. Both the right and left lungs also revealed interstitial mononuclear inflammatory infiltrates, which are dominated by lymphocytes. Multinucleated syncytial cells with atypical enlarged pneumocytes, characterized by large nuclei, amphophilic granular cytoplasm, and prominent nucleoli were observed in the intra-alveolar spaces, which showed viral cytopathic like changes [85]. There were no obvious intracytoplasmic or intranuclear viral inclusions were seen. In addition, the liver biopsy specimen of the same patient with COVID-19 revealed moderate microvesicular steatosis, mild lobular, and portal activity which indicates that the injury might have been caused by either SARS-CoV-2 infection or drug induced liver injury. There was no other substantial damage observed in the heart tissue except a few interstitial mononuclear inflammatory infiltrates [85]. According to Sufang et al., 2020, who also carried out postmortem fine-needle core biopsies on some selected organs (liver, heart, and lungs) on four patients who also died of COVID-19 pneumonia, each of these patients had one or two underlying diseases, which include 
immunocompromised status (chronic lymphocytic leukemia and renal transplantation) or some other conditions, which are liver cirrhosis, diabetes, and high blood pressure [86]. The time frame from the onset of the disease to death for the patients ranged from 15 to 52 days. The main features observed in their histology were in the epithelial tissues, formation of hyaline membrane, and hyperplasia of type II pneumocytes, all the components of diffuse alveolar damage. Fibroblast proliferation with extracellular matrix and fibrin forming clusters in airspaces is evident with an abundant intraalveolar neutrophilic infiltration, consistent with super imposed bacterial bronchopneumonia in one of the patients. The liver showed a mild lobular infiltration with small lymphocytes and centrilobular sinusoidal dilation and a patchy necrosis was also observed [86].

The heart showed only focal mild fibrosis and mild myocardial hypertrophy. The postmortem examination showed an advanced diffused alveolar damage as well as superimposed bacterial pneumonia in some of the patients. The histomorphological changes observed in the heart and liver were most likely to be secondary or caused as a result of the effects of the underlying disease [86].

\section{Complications of COVID-19 Infection}

\section{Acute respiratory syndrome}

The presence of ACE2 on the cells of the heart, kidney, and lungs encourages the SARS viruses infection [87] and about $42 \%$ of COVID-19 patients do develop ARDS [88]. Diabetes mellitus is also a factor associated with the development of ARDS [78]. Other diseases that can cause complications in COVID-19 patients include hypertension, cardiovascular disease, and chronic kidney disease [88], [89]. Medical laboratory findings associated with the development of ARDS include lymphopenia, neutrophilia, elevated CRP, elevated blood urea nitrogen, prolonged prothrombin time, elevated d-dimer, and elevated lactate dehydrogenase (LDH) [88], [89].

About $36 \%$ of ARDS cases are mild, $45 \%$ cases are moderate while $18.9 \%$ cases are severe [17]. Mortality increases with the severity of the disease. Patients above 65 years of age do have worse degree of ARDS and they also have higher mortality likelihood [89]. Medical laboratory markers that can predict the mortality of COVID-19 ARDS patients include low albumin, elevated blood urea nitrogen, and elevated LDH [88], [89].

\section{Myocardial injury}

Most commonly causes of COVID-19 related deaths are usually associated with the hearts and lungs [90]. There are two main theories explaining the mechanism by which myocardial injury occurs with COVID-19. The first theory explains that the heart has similar ACE2 levels as that of the lungs [77], which allows viral entry into the myocardial cells [91]. The second theory involves a cytokine storm causing myocardial injury [91]. Myocardial injury includes heart failure, myocarditis, acute coronary syndrome, hypotension, or shock and sepsis [92]. To have a definitive characterization of the injury, endocardial biopsy is possibly required and magnetic resonance is required [92].

Arrhythmias have been observed to arise with severe COVID-19 cases [93], [94]. Malignant arrhythmias, including ventricular tachycardia and fibrillation, always occur at a rate of $6 \%$ and can be elevated more frequently in patients with elevated troponin levels $(17.3 \%$ of patients with elevated troponin) [85]. Heart failure is commonly observed in severe cases of COVID-19, irrespective of previous cardiac history [85]. This presents with elevated levels of $\mathrm{N}$-terminal pro B-type natriuretic peptide (NT pro-BNP) and troponin levels, mostly in severe cases [49]. Some studies have also revealed that pulmonary hypertension which causes right heart failure can also contribute to these cases.

Elevated high sensitivity troponin (HS-troponin) and creatinine kinase-myocardial brand (CK-MB) levels can also self-sufficiently predict severe COVID-19 cases [88], [92], [93], [94], [95]. A recent meta-analysis revealed that troponin is more elevated in severe cases [96]. Cytokines do not predict severity [88]. It has been revealed that patients with elevated HS-troponin ( $\square 28 \mathrm{ng} / \mathrm{L}$ ) and CK-MB are suspected to have myocarditis or heart failure [7], [88].

\section{Acute kidney injury}

Acute kidney injury presents with elevated urea and cystatin-C levels in severe COVID-19 infection [89]. Concerning the cause of acute kidney injury, there are two hypotheses to it. One of the hypotheses is from kidney able to harbor more ACE-2 levels than the lung or heart, most especially in the proximal convoluted tubules. However, COVID-19 RNA is not encountered in the urine. The second theory has to do with the injury incurred through a cytokine storm [96]. Patients may need to do continuous renal replacement therapy (CRRT) due to the severity of kidney injury. Speculation exists concerning CRRT potentially serving as a way of removing large cytokine levels from the system, regardless of kidney injury [96].

The prognosis predictors of COVID-19 infection include cardiovascular disease, hypertension, cerebrovascular disease, and chronic kidney disease [48] which can all result in severe conditions. In patients with cardiovascular disease, they present with a $10.5 \%$ coronary flow reserve (CFR); other diseases 
that can also present with a high CFR include chronic lung diseases (6.3\%); cancer (5.6\%); hypertension $(6.0 \%)$; and diabetes.

\section{Conclusion}

The diagnostic analysis of this new infection is majorly by NAAT such as real time RT-PCR followed by nucleic acid sequencing. Although some serologic and immunologic assays such as ELISA and ICG lateral flow assay have been developed which detects the IgM and IgG antibodies, there are still lots of cautious remarks on the direct adoption of these tests due to the need for more studies to determine the immunologic capabilities and strength of the antibodies in prevention of future infection. Based on severity, the laboratory features of COVID-19 infection include lymphopenia, eosinopenia, reduced procalcitonin along with leucocytosis, increased D-dimer, CRP, SAA, fibrin, FDP with mild to moderate increase in $\mathrm{PT}$, and $\mathrm{APTT}$ while the major pathologic presentations present with features of acute respiratory syndrome, myocardial injury, and acute kidney injury. Furthermore, some inflammatory markers such as IL-2,IL-6, IL-7, IL-10, GCSF, MCP10, IP10, and TNF- $\alpha$ are apparently increased in COVID-19 infection signaling cytokine storm in the course of the infection and associated SIC. Therefore, as much as there are some established pathologies, diagnosis, and laboratory features of COVID-19 by clinical presentation and hospitalization, more studies are required to identify the capabilities, characteristics and tendencies of this novel virus as well as the most efficient prevention and treatment.

\section{Author's Contributions}

All authors contributed responsibly to this manuscript, have accepted accountability for the entire content, and approved its submission.

\section{References}

1. Zhang JJ, Dong $X$, Cao $Y Y$, Yuan $Y D$, Yang $Y B$, Yan YQ, et al. Clinical characteristics of 140 patients infected with SARS-CoV-2 in Wuhan, China. Allergy. 2020;75(7):173041. https://doi.org/10.1111/all.14238 PMid:32077115

2. World Health Organization. WHO Director General's Opening Remarks at the Media Briefing on Coronavirus Disease (COVID2019). Geneva: World Health Organization; 2020. Available from: https://www.who.int/dg/speeches/detail. [Last accessed on 2020 Mar 11]

3. Center for Disease Control and Prevention. Novel Coronavirus Wuhan, China; 2020. Available from: https://www.cdc.gov/ coronavirus/2019-nCoV/summary.html. [Last accessed on 2020 Apr 01].

4. World Health Organization. Coronavirus Disease (COVID2019) Situation Reports. Available from: https://www. who.int/emergencies/diseases/novel-coronavirus-2019/ situationreports. [Last accessed on 2020 Feb 19].

5. Fehr AR, Channappanavar R, Perlman S. Middle East respiratory syndrome: Emergence of a pathogenic human coronavirus. Annu Rev Med. 2017;68(1):387-99. https://doi. org/10.1146/annurev-med-051215-031152

PMid:27576010

6. Chen Y, Liu Q, Guo D. Emerging coronaviruses: Genome structure, replication, and pathogenesis. J Med Virol. 2020;92:418-23. https://doi.org/10.1002/jmv.25681 PMid:31967327

7. Huang $\mathrm{C}$, Wang $\mathrm{Y}$, Li X, Ren L, Zhao J, Hu Y, et al. Clinical features of patients infected with 2019 novel coronavirus in Wuhan, China. Lancet. 2020;395(10223):497-506. https://doi. org/10.1016/s0140-6736(20)30183-5 PMid:31986264

8. Wang $Y$, Wang $Y$, Chen $Y$, Qin $Q$. Unique epidemiological and clinical features of the emerging 2019 novel coronavirus pneumonia (COVID-19) implicate special control measures. J Med Virol. 2020;92(6):568-76. https://doi.org/10.1002/ jmv. 25748

PMid:32134116

9. Guan W, Ni Z, Hu Y, Liang WH, Ou CQ, He JX, et al. Clinical Characteristics of 2019 Novel Coronavirus Infection in China. New York: medRxiv; 2020.

10. Lu R, Zhao X, Li J, Niu P, Yang B, Wu H, et al. Genomic characterisation and epidemiology of 2019 novel coronavirus: Implications for virus origins and receptor binding. Lancet. 2020;395(10224):565-74

PMid:32007145

11. Zhou P, Yang XL, Wang, XG, Hu B, Zhang L, Zhang W, et al Discovery of a Novel Coronavirus Associated with the Recent Pneumonia Outbreak in Humans and its Potential Bat Origin. NewYork: bioRxiv; 2020

12. Tan $\mathrm{W}$, Zhao X, Ma X, Wang $\mathrm{W}$, Niu $\mathrm{P}, \mathrm{Xu} \mathrm{W}$, et al. A nove coronavirus genome identified in a cluster of pneumonia casesWuhan, China 2019-2020. China CDC Wkly. 2020;2(4):61-2. https://doi.org/10.46234/ccdcw2020.017

13. World Health Organization. Emergency Diseases: Novel Corona Virus. Available from: https://www.who.int/emergencies/ diseases/novel-coronavirus-2019/dashboard. [Last accessed on 2020 Mar 10]

14. Nigeria Center for Disease Control and Prevention. Factsheets on COVID-19. Available from: https://www.covid19.ncdc.gov.ng. [Last accessed on 2020 Mar 10].

15. Tang B, Wang X, Li Q, Bragazzi NL, Tang S, Xiao Y, et al Estimation of the transmission risk of the 2019-nCoV and its implication for public health interventions. J Clin Med. 2020;9(2):462. https://doi.org/10.2139/ssrn.3525558 PMid:32046137

16. Chen J. Pathogenicity and transmissibility of 2019-nCoV-a quick overview and comparison with other emerging viruses. Microbes Infect. 2020;22(2):69-71. https://doi.org/10.1016/j. micinf.2020.01.004

17. Liu Y, Gayle AA, Wilder-Smith A, Rocklöv J. The reproductive number of COVID-19 is higher compared to SARS coronavirus. J Travel Med. 2020;27(2):taaa021. https://doi.org/10.1093/jtm/ 
taaa021

PMid:32052846.

18. Zhao S, Lin Q, Ran J, Musa SS, Yang G, Wang W, et al. Preliminary estimation of the basic reproduction number of novel coronavirus (2019-nCoV) in China, from 2019 to 2020: A datadriven analysis in the early phase of the outbreak. Int $\mathrm{J}$ Infect Dis. 2020;92:214-7. https://doi.org/10.1101/2020.01.23.916395 PMid:3200764

19. Atere AD, Oduwole OA, Okpoli HC, Hassan AO. Coronavirus: Resilient nightmare of the COVID-19 pandemic in Africa. J Med Lab Sci. 2020;30(1):90-5.

20. Zhu N, Zhang D, Wang W, Li X, Yang B, Song J, et al. A novel coronavirus from patients with pneumonia in China, 2019. N Engl J Med. 2020;382(8):727-33. PMid:31978945

21. Adhikari S, Meng S, Wu Y, Mao YP, Ye RX, Wang QZ, et al. Epidemiology, causes, clinical manifestation and diagnosis, prevention and control of coronavirus disease (COVID-19) during the early outbreak period: A scoping review. Infect Dis Poverty. 2020;9(1):29. https://doi.org/10.1186/s40249-020-00646-x PMid:32183901

22. National Health Commission of People's Republic of China. Prevent Guideline of 2019-nCoV; 2020. Available from: http://www.nhc.gov.cn/xcs/yqfkdt/202001/ bc661e49b5bc487dba182f5c49ac445b.shtml. [Last accessed on 2020 Apr 03].

23. Su S, Wong G, Shi W, Liu J, Lai AC, Zhou J, et al. Epidemiology, genetic recombination, and pathogenesis of coronaviruses. Trend Microbiol. 2016;24(6):490-502.

PMid:27012512

24. Peiris JS, Guan Y, Yuen KY. Severe acute respiratory syndrome. Nat Med. 2004;10(12 Suppl):S88-97. https://doi.org/10.1038/ nm1143

PMid:15577937.

25. Zaki AM, Van Boheemen S, Bestebroer TM, Osterhaus AD, Fouchier RA. Isolation of a novel coronavirus from a man with pneumonia in Saudi Arabia. N Engl J Med. 2012;367(19):181420. https://doi.org/10.1056/nejmoa1211721

PMid:23075143

26. Chinese Center for Disease Control and Prevention. Environmental Samples from the South China Seafood Market in Wuhan, Hubei Province, China; 2020. Available from: http:/l www.chinacdc.cn/yw_9324/202001/t20200127_211469.html. [Last accessed on 2020 Apr 03]. https://doi.org/10.46234/ ccdcw2020.022

27. Lu H, Tang CW, Tang Y. Outbreak of pneumonia of unknown etiology in Wuhan, China: The mystery and the miracle. J Med Virol. 2020;92(4):401-2. https://doi.org/10.1002/jmv.25678 PMid:31950516

28. Ahmed T, Noman M, Almatroudi A, Shahid M, Khurshid M, Tariq F, et al. Coronavirus Disease 2019 Assosiated Pneumonia in China: Current Status and Future Prospects. Basel, Switzerland: Preprints Organization, MDPI Company; 2020. https://doi.org/10.20944/preprints202002.0358.v3

29. Xu X, Chen P, Wang J, Feng J, Zhou H, Li X, et al. Evolution of the novel coronavirus from the ongoing Wuhan outbreak and modeling of its spike protein for risk of human transmission. Sci China Life Sci. 2020;63(3):457-60. https://doi.org/10.1007/ s11427-020-1637-5 PMid:32009228

30. Aditya A, Kendall C, Pamela C, Nicole MG, Pinky L, Blake O, et al. From Bench to Bedside. Student Handbook. 1-35.

31. Suzuki $\mathrm{K}$, Wada $\mathrm{H}$, Imai $\mathrm{H}$, Iba $\mathrm{T}$, Thachil $\mathrm{J}$, Toh $\mathrm{CH}$, et al. A re-evaluation of the D-dimer cut-off value for making a diagnosis according to the ISTH overt-DIC diagnostic criteria:
Communication from the SSC of the ISTH. J Thromb Haemost. 2018;16(7):1442-4. https://doi.org/10.1111/jth.14134 PMid:29846034

32. Connors JM, Levy JH. COVID-19 and its implications for thrombosis and anticoagulation. Blood. 2020;135(23):2033-40. https://doi.org/10.1182/blood.2020006000 PMid:32339221

33. Varga Z, Flammer AJ, Steiger $P$, Haberecker $M$, Andermatt $R$, Zinkernagel AS, et al. Endothelial cell infection and endotheliitis in COVID-19. Lancet. 2020;395(10234):1417-8. https://doi. org/10.1016/s0140-6736(20)30937-5 PMid:32325026

34. Iba T, Levy JH, Thachil J, Wada H, Levi M, Scientific and Standardization Committee on DIC of the International Society on Thrombosis and Haemostasis. The progression from coagulopathy to disseminated intravascular coagulation in representative underlying diseases. Thromb Res. 2019;179:114. https://doi.org/10.1016/j.thromres.2019.04.030 PMid:31059996

35. Iba $\mathrm{T}$, Levy JH, Wada $\mathrm{H}$, Thachil J, Warkentin TE, Levi M, Subcommittee on Disseminated Intravascular Coagulation. Differential diagnoses for sepsis-induced disseminated intravascular coagulation: Communication from the SSC of the ISTH. J Thromb Haemost. 2019;17(2):415-9. https://doi. org/10.1111/jth.14354

PMid:30618150

36. Mason RJ. Pathogenesis of COVID-19 from a cell biology perspective. Eur Respir J. 2020;55(4):2000607. https://doi. org/10.1183/13993003.00607-2020 PMid:32269085

37. Hoffmann M, Kleine-Weber H, Schroeder S, Krüger N, Herrler T, Erichsen S, et al. SARS-CoV-2 cell entry depends on ACE2 and TMPRSS2 and is blocked by a clinically proven protease inhibitor. Cell. 2020;181(2):271-80. https://doi.org/10.1016/j. cell.2020.02.052

PMid:32142651

38. Sims AC, Baric RS, Yount B, Burkett SE, Collins PL Pickles RJ. Severe acute respiratory syndrome coronavirus infection of human ciliated airway epithelia: Role of ciliated cells in viral spread in the conducting airways of the lungs. J Virol. 2005;79(24):15511-24. https://doi.org/10.1128/ jvi.79.24.15511-15524.2005

PMid:16306622

39. Kumar PA, Hu Y, Yamamoto Y, Hoe NB, Wei TS, Mu D, et al. Distal airway stem cells yield alveoli in vitro and during lung regeneration following H1N1 influenza infection. Cell. 2011;147(3):525-38. https://doi.org/10.1016/j.cell.2011.10.001 PMid:22036562

40. Yee M, Domm W, Gelein R, Bentley KL, Kottmann RM, Sime PJ, et al. Alternative progenitor lineages regenerate the adult lung depleted of alveolar epithelial Type 2 cells. Am J Respir Cell Mol Biol. 2017;56(4):453-64. https://doi.org/10.1165/ rcmb.2016-0150oc PMid:27967234

41. Coleman JJ, Manavi K, Marson EJ, Botkai AH, Sapey E. COVID-19: To be or not to be; that is the diagnostic question. Postgrad Med J. 2020;96(1137):392-8. https://doi.org/10.1136/ postgradmedj-2020-137979 PMid:32522844

42. Zou L, Ruan F, Huang M, Liang L, Huang $\mathrm{H}$, Hong $\mathrm{Z}$, et al SARS-CoV-2 viral load in upper respiratory specimens of infected patients. N Engl J Med. 2020;382(12):1177-9. https:// doi.org/10.1056/nejmc2001737

PMid:32074444

43. Holshue ML, DeBolt C, Lindquist S, Lofy KH, Wiesman J, 
Bruce $\mathrm{H}$, et al. First case of 2019 novel coronavirus in the United States. N Engl J Med. 2020;382(10):929-36.

PMid:32004427

44. Rothe C, Schunk M, Sothmann P, Bretzel G, Froeschl G, Wallrauch C, et al. Transmission of 2019-nCoV infection from an asymptomatic contact in Germany. N Engl J Med. 2020;382(10):970-1. https://doi.org/10.1056/nejmc2001468 PMid:32003551

45. Chan JF, Yip CC, To KK, Tang TH, Wong SC, Leung KH, et al. Improved molecular diagnosis of COVID-19 by the novel, highly sensitive and specific COVID-19-RdRp/Hel real-time reverse transcription-PCR assay validated in vitro and with clinical specimens. J Clin Microbiol. 2020;58(5):e00310-20. https://doi. org/10.1128/jcm.00310-20

PMid:32132196

46. Center for Disease and Control and Prevention. Coronavirus 2019-nCoV Laboratory Guidelines for Clinical Specimens. Available from: https://www.cdc.gov/coronavirus/2019-nCoV/ lab/guidelines-clinical-specimens.html. [Last accessed on 2020 May 10].

47. Wang W, Xu Y, Gao R, Lu R, Han K, Wu G, et al. Detection of SARS-CoV-2 in different types of clinical specimens. JAMA. 2020;323(18):1843-4. https://doi.org/10.1001/jama.2020.3786 PMid:32159775

48. Cheng Y, Canuto VM, Howard AM, Ackerman AS, Kelley M, Fridlind AM, et al. A second-order closure turbulence model: New heat flux equations and no critical Richardson number. J Atmos Sci. 2020;77(8):2743-59. https://doi.org/10.1175/ jas-d-19-0240.1

49. Tang A, Tong ZD, Wang HL, Dai YX, Li KF, Liu JN, et al. Detection of novel coronavirus by RT-PCR in stool specimen from asymptomatic child, China. Emerg Infect Dis. 2020;26(6):13379. https://doi.org/10.3201/eid2606.200301

PMid:32150527

50. Zhang W, Du RH, Li B, Zheng XS, Yang XL, Hu B, et al. Molecular and serological investigation of 2019-nCoV infected patients: Implication of multiple shedding routes. Emerg Microbes Infect. 2020;9(1):386-9. https://doi.org/10.1080/2222 1751.2020.1729071

PMid:32065057

51. Mondanizadeh $M$, Rahimi $E$, Sarmadian $H$, Jamalian $M$, Khansarinejad B. Evaluation of SARS-CoV-2 Existence in Blood, Urine, and Rectal Swab in Positive Patients with Different Virus Titers. United States: Research Square; 2020. https://doi. org/10.21203/rs.3.rs-20499/v1

52. Carter LJ, Garner LV, Smoot JW, Li Y, Zhou Q, Saveson CJ, et al. Assay techniques and test development for COVID-19 diagnosis. ACS Cent Sci 2020;6(5):591-605. https://doi. org/10.1021/acscentsci.0c00501

PMid:32382657

53. Wang $\mathrm{H}$, Li X, Li T, Zhang $\mathrm{S}$, Wang $\mathrm{L}$, Wu $\mathrm{X}$, et al. The genetic sequence, origin, and diagnosis of SARS-CoV-2. Eur J Clin Microbiol Infect Dis. 2020;39(9):1629-35. https://doi. org/10.1007/s10096-020-03899-4 PMid:32333222

54. World Health Organization. Laboratory Biosafety Manual. $3^{\text {rd }}$ ed. Geneva: World Health Organization; 2004.

55. World Health Organization. Laboratory Testing for 2019 Nove Coronavirus (2019-nCoV) in Suspected Human Cases. Geneva: World Health Organization; 2020.

56. Mizumoto K, Kagaya K, Zarebski A, Chowell G. Estimating the asymptomatic proportion of coronavirus disease 2019 (COVID-19) cases on board the Diamond Princess Cruise Ship, Yokohama, Japan, 2020. Euro Surveill. 2020;25(10):2000180. https://doi.org/10.2807/1560-7917.es.2020.25.10.2000180
PMid:32183930

57. Xia J, Tong J, Liu M, Shen Y, Guo D. Evaluation of coronavirus in tears and conjunctival secretions of patients with SARSCoV-2 infection. J Med Virol. 2020;92(6):589-94. https://doi. org/10.1002/jmv.25725

PMid:32100876

58. American College of Physicians. COVID-19 Found in Sputum and Feces Samples after Pharyngeal Specimens No Longer Positive. Rockville, MD: Science Daily; 2020.

59. Notomi T, Okayama H, Masubuchi H, Yonekawa T, Watanabe $\mathrm{K}$, Amino N, et al. Loop-mediated isothermal amplification of DNA. Nucleic Acids Res. 2020;28(12):E63. https://doi.org/10.1093/ nar/28.12.e63 PMid:10871386

60. Hong TC, Mai QL, Cuong DV, Parida M, Minekawa H, Notomi $\mathrm{T}$, et al. Development and evaluation of a novel loop-mediated isothermal amplification method for rapid detection of severe acute respiratory syndrome coronavirus. J Clin Microbiol. 2004;42(5):1956-61. https://doi.org/10.1128/ jcm.42.5.1956-1961.2004

PMid:15131154

61. Seliger H, Rampal JB. Microarrays. In: Methods in Molecular Biology. $2^{\text {nd }}$ ed., Vol. 1. Humana Press; 2017. p. 381

62. Guo X, Geng P, Wang Q, Cao B, Liu B. Development of a single nucleotide polymorphism DNA microarray for the detection and genotyping of the SARS coronavirus. J Microbiol Biotechnol. 2014;24(10):1445-54. https://doi.org/10.4014/jmb.1404.04024 PMid:24950883

63. Hardick J, Metzgar D, Risen L, Myers C, Balansay M, Malcom $\mathrm{T}$, et al. Initial performance evaluation of a spotted array Mobile Analysis Platform (MAP) for the detection of influenza A/B, RSV, and MERS coronavirus. Diagn Microbiol Infect Dis. 2018;91(3):245-7. https://doi.org/10.1016/j. diagmicrobio.2018.02.011 PMid:29550057

64. Centers for Disease Control and Prevention. Crisis Managemnet Documents for Serologic Testing; 2020. Available from: https:// www.aphl.org/programs/preparedness/crisismanagement/ documents/Serologic-testingfor-COVID-19.pdf. [Last accessed on 2020 Mar 10].

65. Food and Drug Administration. Emergency Use Authorisation of Serology Test; 2020. Available from: https://www.fda.gov/ media/135659/download. [Last accessed on 2020 Mar 10]

66. Pan Y, Li X, Yang G, Fan J, Tang Y, Zhao J, et al. Serological immunochromatographic approach in diagnosis with SARSCoV-2 infected COVID-19 patients. J Infect. 2020;81(1):e28-32. https://doi.org/10.1016/j.jinf.2020.03.051

PMid:32283141

67. Gorse GJ, Donovan MM, Patel GB. Antibodies to coronaviruses are higher in older compared with younger adults and binding antibodies are more sensitive than neutralizing antibodies in identifying coronavirus-associated illnesses. J Med Virol. 2020;92(5):512-7. https://doi.org/10.1002/jmv.25715 PMid:32073157

68. Fan BE, Chong VC, Chan SS, Lim GH, Lim KG, Tan GB, et al. Hematologic parameters in patients with COVID-19 infection. Am J Hematol. 2020;95(6):E131-4.

PMid:32129508

69. Robin EF, Marcel L, Reecha S, Jeffrey KA. Thrombosis in COVID-19: Clinical Outcomes, Biochemical and Pathological Changes, and Treatments. Centre for Evidence Based Medicine; 2020. Available from: https://www.cebm.net/covid19/thrombosis-in-covid-19-clinical-outcomes-biochemical-andpathological-changes-and-treatments. [Last accessed on 2020 Mar 10] 
70. Panigada M, Bottino N, Tagliabue P, Grasselli G, Novembrino C, Chantarangkul V, et al. Hypercoagulability of COVID-19 patients in intensive care unit: A report of thromboelastography findings and other parameters of hemostasis. J Thromb Haemost. 2020;18(7):1738-42. https://doi.org/10.1111/jth.14850 PMid:32302438

71. Thachil J, Tang N, Gando S, Falanga A, Cattaneo M, Levi M, et al. ISTH interim guidance on recognition and management of coagulopathy in COVID-19. J Thromb Haemost. 2020;18(5):1023-6. https://doi.org/10.1111/jth.14810 PMid:32338827

72. Zhou S, Wang Y, Zhu T, Xia L. CT features of coronavirus disease 2019 (COVID-19) pneumonia in 62 patients in Wuhan, China. Am J Roentgenol. 2020;214(6):1287-94. https://doi. org/10.2214/ajr.20.22975 PMid:32134681

73. Cascella M, Rajnik M, Cuomo A, Dulebohn SC, Di Napoli R. Features, Evaluation and Treatment Coronavirus (COVID-19). Treasure Island, FL: StatPearls Publishing; 2020.

74. Li Q, Guan X, Wu P, Wang X, Zhou L, Tong Y, et al. Early transmission dynamics in Wuhan, China, of novel coronavirusinfected pneumonia. N Engl J Med. 2020;382:1199-207.

75. Shen $\mathrm{K}$, Yang $\mathrm{Y}$, Wang $\mathrm{T}$, Zhao D, Jiang $\mathrm{Y}$, Jin R, et al. Diagnosis, treatment, and prevention of 2019 novel coronavirus infection in children: Experts' consensus statement. World $\mathrm{J}$ Pediatr. 2020;16(3):223-1.

PMid:32034659

76. Ragab D, Eldin HS, Taeimah M, Khattab R, Salem R. The COVID-19 cytokine storm; what we know so far. Front Immunol. 2020;11:1446. https://doi.org/10.3389/fimmu.2020.01446 PMid:32612617

77. Shimizu M. Clinical features of cytokine storm syndrome. In: Cron R, Behrens E, editors. Cytokine Storm Syndrome. Cham: Springer; 2019. p. 31-42. https://doi. org/10.1007/978-3-030-22094-5_3

78. Ruan Q, Yang K, Wang W, Jiang L, Song J. Clinical predictors of mortality due to COVID-19 based on an analysis of data of 150 patients from Wuhan, China. Intensive Care Med. 2020;46(5):846-8. https://doi.org/10.1007/s00134-020-05991-x PMid:32125452

79. Chen G, Wu D, Guo W, Cao Y, Huang D, Wang H, et al. Clinical and immunological features of severe and moderate coronavirus disease 2019. J Clin Invest. 2020;130(5):2620-9. PMid:32217835

80. Gao Y, Li T, Han M, Li X, Wu D, Xu Y, et al. Diagnostic utility of clinical laboratory data determinations for patients with the severe COVID-19. J Med Virol. 2020;92(7):791-6. https://doi. org/10.1002/jmv.25770

PMid:32181911

81. Chen L, Liu H, Liu W, Liu J, Liu K, Shang J, et al. Analysis of clinical features of 29 patients with 2019 novel coronavirus pneumonia. Zhonghua Jie He He Hu Xi Za Zhi. 2020;43:203-8. PMid:32026671

82. Sun D, Li H, LuX, Xiao H, Ren J, Zhang FR, et al. Clinical features of severe pediatric patients with coronavirus disease 2019 in Wuhan: A single center's observational study. World J Pediatr. 2020;16(3):251-9. https://doi.org/10.1007/s12519-020-00354-4 PMid:32193831

83. Zhou P, Yang XL, Wang XG, Shi ZL. A pneumonia outbreak associated with a new coronavirus of probable bat origin. Nature. 2020;579(7798):270-3.

84. XuZ, Shi L, Wang Y, Zhang J, Huang L, Zhang C, et al. Pathologica findings of COVID-19 associated with acute respiratory distress syndrome. Lancet Respir Med. 2020;8(4):420-2. https://doi. org/10.1016/s2213-2600(20)30076-x

PMid:32085846

85. Sufang T, Yong X, Huan L, Li N, Jianchun G, Meiyan L, et al. Pathological study of the 2019 novel coronavirus disease (covid-19) through postmortem core biopsies. Mod Pathol. 2020;33:1007-14.

86. Turner AJ, Hiscox JA, Hooper NM. ACE2: From vasopeptidase to SARS virus receptor. Trends Pharmacol Sci. 2004;25:291-4. https://doi.org/10.1016/j.tips.2004.04.001

PMid: 15165741

87. Wu A, Peng Y, Huang B, Ding X, Wang X, Niu P, et al. Genome composition and divergence of the novel coronavirus (2019nCoV) originating in China. Cell Host Microbe. 2020;27(3):3258. https://doi.org/10.1016/j.chom.2020.02.001 PMid:32035028

88. Liu Y, Yang Y, Zhang C. Clinical and biochemical indexes from 2019-nCoV infected patients linked to viral loads and lung injury. Sci China Life Sci. 2020;63(3):364-74. https://doi.org/10.1007/ s11427-020-1643-8 PMid:32048163

89. Zheng YY, Ma YT, Zhang JY, Xie X. COVID-19 and the cardiovascular system. Nat Rev Cardiol. 2020;17(5):259-60. PMid:32139904

90. Madjid M, Safavi-Naeini P, Solomon SD, Vardeny O. Potential effects of coronaviruses on the cardiovascular system: A review. JAMA Cardiol. 2020;5(7):831-40. https://doi.org/10.1001/ jamacardio.2020.1286 PMid:32219363

91. Driggin E, Madhavan MV, Bikdeli B, Chuich T, Laracy J, Biondi-Zoccai G, et al. Cardiovascular considerations for patients, health care workers, and health systems during the COVID-19 pandemic. J Am Coll Cardiol. 2020;75(18):2352-71. https://doi.org/10.1016/j.jacc.2020.03.031 PMid:32201335

92. Guo T, Fan Y, Chen M, Wu X, Zhang L, He T, et al. Cardiovascular implications of fatal outcomes of patients with coronavirus disease 2019 (COVID-19). JAMA Cardiol. 2020;5(7):811-8. https://doi.org/10.1001/jamacardio.2020.1017 PMid:32219356

93. Zhou F, Yu T, Du R, Fan G, Liu Y, Liu Z, et al. Clinical course and risk factors for mortality of adult inpatients with COVID-19 in Wuhan, China: A retrospective cohort study. Lancet. 2020;395(10229):1054-62. https://doi.org/10.1016/ s0140-6736(20)30566-3

PMid:32171076

94. Lippi G, Lavie CJ, Sanchis-Gomar F. Cardiac troponin I in patients with coronavirus disease 2019 (COVID-19): Evidence from a meta-analysis. Prog Cardiovasc Dis. 2020;63(3):390-1. https://doi.org/10.1016/j.pcad.2020.03.001 PMid:32169400

95. Woelfel R, Corman VM, Guggemos W, Seilmaier M, Zange S, Mueller MA, et al. Clinical Presentation and Virological Assessment of Hospitalized Cases of Coronavirus Disease 2019 in a Travel-Associated Transmission Cluster. New York: MedRxiv; 2020. https://doi.org/10.1101/2020.03.05.20030502 